\title{
EKSPERIMENTASI PEMBELAJARAN BAHASA ARAB MENGGUNAKAN MEDIA GAMBAR PADA KELAS X UNTUK MENINGKATKAN PENGUASAAN MUFRADĀT
}

\author{
Rahmaya Unting Sari \\ Universitas Islam Negeri Sunan Kalijaga \\ Mayahakaza1302@gmail.com \\ Eka Utari Handayani \\ Pascasarjana Universitas Islam Negeri Sunan Kalijaga \\ alexautary@gmail.com
}

\begin{abstract}
The background of this study is the lack of creativity of teachers in using media in learning Arabic at MAN 3 Bantul, Yogyakarta. This study aims to determine the learning process of mufradât with picture media and find out the differences in learning outcomes of students in learning mufradât between experimental classes that use image media and control classes that do not use image media. This research is quantitative research and the type of research is experiment. Data collection is done by the method of testing, observation, and documentation. This experimental research was conducted with a pretest, posttest control group design model. The object used is class X IPS 1 as an experimental class and class X IPS 2 as a control class. While the data analysis technique uses independent samples $t$-test. The results of this study indicate that, there are significant differences between the experimental class and the control class. This difference can be seen from the average value of the control class posttest 66.312 while the posttest value of the experimental class is 90.125. Whereas the " $t$ " Test of the experimental class and the control class posttest produced a Sig. (2-tailed) value of 0,000 $<0.05$, which means that there was a significant difference in mastery of the mufradât between the experimental class and the control class, it can be concluded that Ha was accepted. The results of this analysis indicate that image media can be used as an alternative solution to improve the learning outcomes of students in grade 10 social studies.
\end{abstract}

Keywords: Eksperiment, Media Image, Mufrodat.

\begin{abstract}
Abstrak: Latar belakang dari penelitian ini adalah kurangnya kreatifitas guru dalam menggunakan media pada pembelajaran bahasa Arab di MAN 3 Bantul Yogyakarta. Penelitian ini bertujuan untuk, mengetahui proses pembelajaran mufradât dengan media gambar dan mengetahui perbedaan hasil belajar peserta didik dalam pembelajaran mufradât antara kelas eksperimen yang menggunakan media gambar dengan kelas kontrol yang tidak menggunakan media gambar. Penelitian ini adalah penelitian kuantitatif dan jenis penelitiannya yaitu eksperimen. Pengumpulan data dilakukan dengan metode tes, observasi, , dan dokumentasi. Penelitian eksperimen ini dilakukan dengan model pretes, posttest control group design. Obyek yang digunakan adalah kelas X IPS 1 sebagai kelas eksperimen dan kelas X IPS 2 sebagai kelas kontrol. Sedangkan teknik analisis data menggunakan uji independent samples t-test. Hasil penelitian ini menunjukkan bahwa, terdapat perbedaan yang signifikan antara kelas eksperimen dengan kelas kontrol. Perbedaan ini dapat dilihat dari nilai rata-rata posttest kelas kontrol sebesar 66,312 sedangkan nilai posttest kelas eksperimen sebesar 90,125 . Sedangkan Uji " $t$ " nilai posttest kelas eksperimen dan kelas kontrol menghasilkan nilai Sig.(2-tailed) 0,000 < 0,05 yang artinya terdapat perbedaan yang signifikan pada penguasaan mufradât antara kelas eksperimen dan kelas kontrol, maka dapat disimpulkan bahwa Ha diterima. Hasil analisis ini menunjukkan bahwa media gambar dapat digunakan sebagai solusi alternatif dalam meningkatkan hasil belajar mufradât peserta didik kelas 10 IPS.
\end{abstract}

Kata Kunci : Eksperimen, Media gmbar, Mufrodat. 


\section{PENDAHULUAN}

Pembelajaran bahasa Arab yang didesain dengan baik akan mewujudkan tujuan yang diharapakan. Desain pembelajaran bahasa Arab yang baik ditandai dengan memilih pendekatan, metode, strategi materi, dan media yang sesuai dengan kondisi sisa dan tujuan pembelajaran. ${ }^{1}$ Media pembelajaran merupakan salah satu sarana untuk kegiatan pembelajaran. Media secara harfiah artinya adalah perantara atau pengantar. Sedangkan menurut AECT "Association Education and Communication" media adalah segala bentuk yang digunakan untuk proses penyaluran informasi, sedang yang dipergunakan untuk proses penyaluran informasi, sedangkan menurut NEA (National Eucation association) ${ }^{2}$ media adalah segala benda yang dapat dimanipulasikan, dilihat, didengar, dibaca, dan dibicarakan beserta instrumen yang digunakan untuk kegiatan tersebut. Didalam bahasa Arab, media pengajaran kurang lebih adalah (وسائل اللإيضاح) wasa'il altauhdiyah.3 Ada juga beberapa kalangan yang menyebutnya (المعينات السمعية والبصرية) al-muayyanat al-sam'iyyah al-bashariyyah, yaitu alat pandang dengar. "Bahwa media pengajaran itu berpengaruh besar bagi indra dan lebih memudahkan (dapat menjamin) pemahaman orang yang melihat tidak sama dengan orang yang hanya mendengar".

Dengan kata lain, media adalah segala sesuatu yang dapat menyalurkan kesan dapat merangsang pikiran, perasaan dan kemauan peserta didik. Media pembelajaran dapat dipergunakan untuk mengajarkan unsur-unsur bahasa Arab yaitu: unsur al aswat (suara), unsur al huruf (huruf), unsur al sehingga dapat mendorong terciptanya proses belajar pada mufradāt (kosakata) dan unsur tarakib (jumlah atau kalimat). ${ }^{4}$

Maka dari itu, media dalam pembelajaran bahasa Arab mempunyai peran yang sangat urgent karena media ini dapat membangkitkan motivasi peserta

${ }^{1}$ M. Abdul Hamid, Pembelajaran Bahasa Arab:Penekatan, Metode, Strategi, Materi dan Media, (Malang: UIN Maliki Press), 2008, hlm 4. ${ }^{2}$ AECT "Association For Education and Communication", dalam koyok,dkk., Media pendidikan, (Jakarta: Depdikbud, 1985), hlm.42. ${ }^{3}$ Abdul Halim Ibrahim, Al Muwajjih Al-Fanni Li Mudarrisi Al-Lughah Al-Arabiya, (Kairo:Dar Al-Ma'rif, 1968), hlm. 423.

4 Muhammad Ahmad Salim, Al-Wasa'il Al-Ta'limiyah Fi Ta'limi Al-'Arabiyah Lughah Ajnabiyah ,(Mekkah: Al-Mamlakah Al-'Arabiyah Al-Su'udiyah,1987), hlm.4 
didik, meningkatkan pengertian peserta didik, memberikan data yang kuat atau terpercaya, memadatkan informasi, dan memudahkan menafsirkan data. Pendapat ini sama dengan pendapat Mahmud Yunus bahwa media pengajaran berpengaruh besar bagi indra dan lebih mendahulukan pemahaman. ${ }^{5}$ Menurut Jhon Lennon dalam Azhar Arsyad media pembelajaran mempunyai peran yang sangat urgent karena media ini dapat memangkitkan motivasi peserta didik, meningkatkan pengertia peserta didik, memberikan data yang kuat/terpercaya, memadatkan informasi, dan memudahkan menasirkan data.

$$
\text { إنها أعظم تأُثيرا في الحواس واضمن للفهم ....فا راء كن سمع }
$$

"Bahwa media pengajaran itu berpengaruh besar bagi indra dan lebih memudahkan (dapat menjamin) pemahaman orang yang melihat tidak sama dengan orang yang hanya mendengar".

Media pengajaran dapat membangkitkan rasa senang dan gembira peserta didik, dan memperbaharui semangat mereka. Rasa suka hati mereka untuk ke sekolah akan timbul, dapat memantapkan pengetahuan pada benak para peserta didik, menghidupkan pelajaran karena pemakaian media pengajaran membutuhkan gerak dan karya". ${ }^{6}$

Beberapa pendapat di atas memberikan penjelasan secara tegas bahwa banyak hal keistimewaan media pembelajaran "bahasa Arab" yang sangat mendukung dan mengefektifkan serta menarik dan mengasyikkan pembelajaran bahasa Arab paling tidak dengan penggunaaan media pembelajaran bahasa Arab akan mengurangi beberapa kesan tanggapan negatif yang selama ini bahasa Arab "ditakuti", dicap sulit, sukar, "tidak menarik", membosankan dan berbagai macam cemoohan sinis dan pesimis. Media ini sebagai salah satu solusi dalam mempelajari bahasa arab secara mudah, menarik, dan enjoy.

Salah satu media yang dianggap efektif dalam penyampaian materi pendidikan bahasa Arab adalah media gambar dengan media gambar, pesan atau materi akan tersaji dengan lebih baik dan menarik perhatian. Selain itu, materi akan menjadi lebih mudah untuk diingat dan lebih mendalam kesannya, yakni dengan menggunakan alat yang dapat divisualisasikan dan dapat dinikmati

5 Azhar Arsyad, Bahasa Arab dan Metode Pengajarannya, (Yogyakarta: Pustaka Pelajar, 2010), hlm. 
dengan panca indera, khususnya indera penglihatan (visual). Peranan media gambar menjadi sangat penting, karena secara psikologis manusia lebih cenderung pada sesuatu yang indah, baik dan menarik perhatian, salah satunya adalah menggunakan media gambar tersebut. ${ }^{7}$

Tidak dapat dipungkiri bahwa dalam sebuah proses pembelajaran pasti terdapat berbagai macam permasalahan, begitu juga dalam pembelajaran bahasa Arab, permasalahan tersebut antara lain: 1) Guru kurang kreatif dan inovatif dalam menggunakan media pembelajaran sehingga materi terkesan sulit; 2) Keterbatasan media yang ada atau keterbatasan media sekolah dalam menyedikan media pembelajaran; 3) Masih banyak siswa yang belum mahir berbicara dalam bahasa Arab karena kesulitan menghafal kosakata bahasa Arab; 4) Buku-buku paket bahasa terkesan sulit dan padat dengan materi. Sehingga hal ini menyebabkan siswa belajar bahasa Arab kurang termotifasi; 5) Media bahasa Arab sangat terbatas.karena itu,dibutuhkan guru yang kreatif untuk menemukan dan membuat media pembelajaran bahasa Arab yang menarik. Karena peranan media sangat penting dalam mentransfer pengetahuan bahasa kepada siswa.

Permasalahan semacam ini juga dialami oleh siswa kelas X IPS MAN 3 Bantul Yogyakarta dan akan sangat mengganggu proses pembelajaran bila tidak dikelola dan ditangani dengan baik oleh guru.oleh karena itu, dalam proses pembelajaran perlu diupayakan media yang sesuai dengan kondisi dan tingkat kemampuan pembelajar khususnya pada tingkatan MAN.

Dari hasil penelusuran beberapa literature, peneliti menemukan beberapa karya ilmiah yang berhubungan dengan tema penelitian ini, diantaranya:

Pertama, skripsi yang disusun oleh Mahrus Ali Wardana yang berjudul "Peningkatan Kualitas Hafalan Kosakata Bahasa Arab Dengan Media Permaninan Teka-Teki Silang (Studi Eksperimen Pada Siswa Kelas X Di MA Ali Maksum) Tahun Ajaran 2016/2017.8 Hasil penelitian tersebut menunjukan bahwa terdapat perbedaan yang signifikan pada peningkatan prestasi belajar antara kemampuan asil belajar kelompok eksperimen dan kelompok kontrol yang dapat dilihat dari nilai hasil skor rata-rata post test kelompok kontrol sebesar 75,8667. Sedangkan

${ }^{7}$ Amir Hamzah Suleiman, Media Audio Visual Untuk Pengajaraan, Penerangan, Daftarpenyuluhan, (Jakarta:Grafindo,1998), hlm. 27.

8 Mahrus Ali Wardana, Peningkatan Kualitas Hafalan Kosakata Bahasa Arab Dengan media Permainan Teka-teki silang(Studi Eksperimen Pada Siswa Kelas X Di MA Ali Maksumtahun ajaran 2016/2017), Skripsi Pendidikan Bahasa Arab, (Yogyakarta: UIN Suanan Kalijaga, 2016).td. 
kelompok eksperimen sebesar 89,7333. Peningkatan rata-rata hasil post test kelompok eksperimen sebanyak 13,8666. Persamaan penelitian ini dengan penelitian sebelumnya yaitu bertujuan meningkatkan penguasaan kosakata, sedangkan perbedannya terletak pada media yang digunakan, penelitian ini berfokus pada media gambar.

Kedua, skripsi yang disusun oleh Saidi Nasirun yang berjudul "Upaya Meningkatkan Pemahaman Mufrādat Melalui Metode Card Sort pada pembelajaran bahasa Arab kelas IV Semester II Di MI Nurul Hidayah Trenten Candimulyo Magelang Tahun 2014".9 Hasil penelitian tersebut menunjukan bahwa pembelajaran mufrādat dengan media card sort mampu meningkatkan prestasi belajar siswa pada mata pelajaran bahasa Arab pra tindakan rata-rata skor sebesar 62,00 dengan presentase ketuntasan 40\%, perbedannya terletak pada jenis medianya, objek dan subyek penelitiannya.

Ketiga, skripsi yang disusun oleh Siti Solikha yang berjudul "Eksperimentsi Metode Pembelajaran Mufrādat Bahasa Arab Dengan Menggunakan Media Gambar Pada Siswa Kelas IV Di Madrasah Ibtidaiyah Negeri Jejeran".10Penelitian tersebut menunjukan bahwa pembelajaraan mufrādat dengan media gambar mampu meningkatkan penguasaan mufrādat pada mata pelajaran bahasa Arab, rata-rata di kelas kontrol semula 12,31 menjadi 12,75. Sedangkan kelompok eksperimen rata rata semula sebesar 13,00 menjadi 17,88 , terdapat peningkatan sebesar 4,88 . Persamaannya terletak pada media yang digunakan gambar, pendekatan penelitian kualitatif, perbedaanya hanya pada media gambar yang menggunakan referensi sumber gambar yang berbeda, serta objek dan subjek penelitian yang berbeda.

Pada penelitian ini, penulis ingin melakukan penelitian yang berupa eksperimen dalam memecahkan salah satu permasalahan yang telah disebutkan di atas yaitu dalam hal kosakata bahasa Arab di MAN 3 Bantul dengan cara menghadirkan media pembelajaran pada tingkat MAN, telah disebutkan di atas bahwasanya media gambar dapat membangkitkan rasa senang dan gembira

\footnotetext{
9 Saidi Nasirun, Upaya Meningkatkan Memahaman Mufradāt Melalui Metode card Sort pada Pembelajaaran Bahasa Arab kelas IV Semester II di MI Nurul Hidayah Trenten Candimulyo magelang tahun 2014".Skripsi Pendidikan guru Madrasah Ibidaiyah.(Yogyakara:UIN Sunan Kalijaga,2014) ${ }^{10}$ Siti Solikha, "Eksperimentsi Metode Pembelajaran Mufradāt Bahasa Arab Dengan menggunakan Media Gambar Pada Siswa Kelas IV Di Madrasah Ibtidaiyah Negeri Jejeran"
} 
peserta didik dan memperbahurui semangat mereka. Oleh karenaa itu, peneliti akan menggunakan media gambar dalam proses pembelajaran yang akan menggunakan kitab Al-Arabiyah Linnasyiin dalam pembelajaran aktif di MAN 3 Bantul. Salah satu kitab yang dapat membuat anak merasa senang untuk belajar yaitu kitab Al-Arrabiyah lil An-nasyiin yang lebih dominan gambar dibanding teks bahasa Arab yang terkesan padat dan membosankan.

Berdasarkan permasalahan-permasalahan diatas, maka penulis merasa pentingnya mengadakan penelitian eksperimen media gambar pada pembelajaran bahasa Arab di MAN 3 Bantul. Adapun tujuan utama dari penelitian ini adalah untuk meningkatkan kemampuan penguasaan mufrodat siswa.

\section{METODE PENELITIAN}

Pendekatan yang digunakan dalam penelitian ini adalah pendekatan kuantitatif. Sedangkan jenis penelitiannya adalah penelitian eksperimen karena dalam penelitian eksperimen ada perlakuan (treatment). Penelitian ini merupakan penelitian eksperimen kuasi (quasi eksperimental) atau biasa disebut dengan eksperimen semu. Dalam penelitian eksperimen kuasi (quasi ksperimentl)terdapat dua jenis desain yaitu time-series design dan non-equivalent control group design. ${ }^{11}$ Adapun jenis desain eksperimen kuasi dalam penelitian ini adalah nonequivalent control grup design.

Penentuan data dalam penelitian ini dikumpulkan melalui populasi dan sampel. Adapun populasi dalam penelitian ini adalah peserta didik kelas X IPS di MAN 3 Bantul Yogyakarta. Sedangkan sampel diambil peneliti hanya 2 kelas yaitu kelas eksperimen dan kelas kontrol. Pengambilan sample dalam penelitian ini peneliti memilih untuk menggunakan Probability Sampling. Sedangkan Jenis Probability Sampling yang peneliti ambil adalah jenis Cluster Sampling

Teknik pengumpulan data dengan cara tes, observasi, wawancara, dan dokumentasi. Instrument pengumpulan data dengan cara tes yang berupa butir soal dalam bentuk pre-test dan post-test. Uji realiabilitas instrument dengan cara

11Sugiyono, Metode Penelitian : Pendekatan Kuantitatif, Kualitatif .Dan R\&D, (Bandung: 
uji normalitas ini dengan rumus uji normalitas kolmogorof - smirov ${ }^{12}$ dan uji homogenitas dengan uji F.

\section{KAJIAN PUSTAKA}

\section{Media Pembelajaran}

Menurut Oemar Hamalik pembelajaran adalah suatu kombinasi yang meliputi unsur-unsur manusiawi, material, fasilitas, perlengkapan, dan prosedur yang saling mempengaruhi untuk tujuan pembelajaran. ${ }^{13}$ Pembelajaran juga mengandung arti suatu proes interkasi antara peserta didik dengan lingkungan, sehinga terjadi perubahan perilaku kearah yang lebih baik. Dalam interaksi tersebut banyak faktor-faktor yang mempengaruhi baik faktor internal maupun faktor eksternal.

Dalam buku karangan Theo Riyanto pembelajaran adalah suatu proses belajar yang melibatkan interaksi antara guru dan anak didik dengan berbagai komponen yang mempengaruhinya, karena efektivitas belajar mengajar sangat ditentukan oleh bagaimana terjadinya interaksi yang dinamis antara pelajar dan pembelajaran atau antara guru yang melaksanakan fungsi mengajar dan siswa yang melaksanakan fungsi belajar. Bown (1987) merinci karakteristik pembelajaran, antara lain: 14a) Mendapatkan (secara disadari); b)Referensi informasi ketrampilan; c)Mencakup beberapa bentuk praktis,berupa penguatan secara praktis; d) Pengubah perilaku

Sedangkan bahasa Arab merupakan suatu alat komunikasi antara sesama manusia, dari itu lahirlah bahasa masyarakat tertentu dengan tanpa harus bermusyawarah terlebih daahulu karena setiap masyarakat menciptakan bahasa sendiri-sendiri yang berfungsi untuk berkomunikasi dikalangan mereka sendiri, oleh sebab itu lahirlah bahasa yang beraneka ragam sesuai dengan taraf masyarakat dimana bahasa itu lahir. ${ }^{15}$

12 Misbahudin dan Iqbal Hasan, Analisis Data penelitian Dengan Statistik, (Jakarta; PT Bumi

Aksara, 2013), hlm. 281.

13 Oemar Hamalik, Kurikulum dan Pembelajaran,( Jakarta: Bumi Aksara, 2003), hlm. 57.

14 Theo Riyanto, Pembelajaran Sebagai Proses Bimbingan Pribadi , (Jakarta: PT.Grasindo, 2002), hlm 1.

${ }^{15}$ Abdul Muin, Analisis Kontrastif Bahasa Arab dan Bahasa Indonesia Telaah Terhadap Fonetik Dan Morfologi, (Jakarta: Pustaka Al Husna Baru, 2004). hlm 19. 


\section{Media Gambar}

Oemar Hamalik mengartikan media gambar sebagai segala sesuatu yang diwujukan secara visual dalam bentuk dua dimensi sebagai curahan perasaan atau pikiran yang terdiri atas: lukisan, ilustrasi, karikatur, kartun, poster, gambar, seri, potret, dan slide ${ }^{16}$. Media gambar merupakan sesuatu sarana pembelajaran yang berbentuk gambar yang makna situasi, keadaaan, peristiwa, dan benda.

Kata media berasal dari kata Latin "medius" yang artinya "tengah". Secara umum, media adalah semua bentuk perantara untuk menyebar, membawa atau menyampaikan sesuatu pesan (message) dan gagasan kepada penerima. ${ }^{17}$ Sedangkan menurut Depdiknas istilah media berasal dari "medium" yang secara harfiah berarti perantara atau pengantar. Makna umumnya adalah segala sesuatu yang dapat menyalurkan informasi dari sumber informasi kepada penerima informasi. ${ }^{18}$

Media bahasa Arab adalah wasail yang berarti perantara atau pengantar pesan dari pengirim kepada penerima. Menurut Abdul Alim Ibrahim media adalah Gerlach \& Ely mengatakan bahwa media secara garis besar adalah manusia, materi, atau kejadian yang membangun kondisi yang membuat peserta didik mampu memperoleh pengetahuan, keterampilan, atau sikap. ${ }^{19}$

Media pembelajaran adalah alat yang dapat membantu proses belajar mengajar dan berfungsi untuk memperjelas makna pesan yang disampaikan, sehingga dapat mencapai tujuan pembelajaran dengan lebih baik dan sempurna. ${ }^{20}$

Sedangkan Amir Hamzah Sulaiman mengemukakan pedapatnya tentang kriteria media gambar. ${ }^{21}$, yaitu: a) Kita harus mempunyai tujuan yang pasti, jelas dan terperinci untuk kegunaannya; b) Menyesuaikan dengan tingkat

16 Oemar hamalik, Media pendidikan, (Jakarta:PT.Citra Aditya Bakti,1980), hlm.43

17 Azhar Arsyad, Bahasa Arab dan Metode... , hlm.86.

18 Agus Purwanto, "Media Pembelajaran Bahasa Inggris mengenai Telling Time, Hospital, Dan Shapes Untuk Anak Sekolah Dasar, Journal Speed - Sentra Penelitian Engineering dan Edukasi, http://speed.web.id/ejournal/index.php/Speed/article/view/227, hlm. 43, tahun 2013, akses 4

Februari 2018, pukul 15.00

19 M. Khalilullah, Media Pembelajaran Bahasa Arab, (Yogyakarta; Aswaja Pressindo, 2012), hlm. 23.

20 Cecep Kustandi dan Bambang Sutjipto, Media Pembelajaran Manual dan Digital, (Bogor: Ghalia Indonesia, 2011), hlm. 8. ${ }^{21}$ Sri Utami Nababan, Metodologi Pengajaran Bahasa, Jakarta: Gramedia 1993, hlm. 21. 
perkembangan murid atau kondisi siswa,nilai gambar justru tergantung dari bagaimana sseorang menyerap makna yang terkandung didalamnya; c) Gambar harus dapat mengarahkan minat orang yang sedang menikmati untuk mendapatkan jawaban atas pertanyaan yang timbul dalam pikirannya; d) Gambar harus merangsang partisipasi siswa atau anak didik, supaya ia suka bicara tentang gambar yang dilihatnya.

Berdasarkan penjelasan di atas media gambar yaitu sebagai alat bantu dalam kegiatan belajar yang memberikan pengalaman visual pada anakguna mendorong motivasi belajar dan mempermudah konsep yang kompleks dan abstrak menjadi lebi sederhana, konkret dan mudah dipahami.

\section{Pembelajaran Mufradhat}

Kosakata atau dalam bahasa Arab disebut mufradāt. Kosakata ada yang mendefinisikan sebagai himpunan semua kata-kata yang dimengerti oleh orang tersebut dan kemungkinan akan digunakannya untuk menyusun kalimat baru. ${ }^{22}$ Soedjito memaparkan bahwa kosakata merupakan: (1) semua kata yang terdapat dalam satu bahasa; (2) kekayaan kata yang dimiliki oleh seorang pembicara; (3) kata yang dipakai dalam satu bidang ilmu pengetahuan; dan (4) daftar kata yang disusun seperti kamus disertai penjelasan secara singkat dan praktis. ${ }^{23}$

Dari pengertian di atas pengertian kosakata dapat diartikan kata atau bagian dasar untuk mempelajari bahasa apapun dan dipakai dalam sau bidang ilmu pengetahuan disertai penjelasan singkat dan praktis. Berikut ini tahapan dalam pembelajaran mufrodat: a) Apersepsi: Dalam dunia pendidikan, apersepsi dapat dipahami sebagai sebuahproses untuk membentuk pemahaman bagi peserta didik. Seorang guru yang akan mengajarkan materi pelajaran yang baru akan menghubungkan materi yang baru tersebut dengan materi yang telah dipelajari oleh peserta didik sebelumnya. Hal tersebut untuk mempermudah peserta didik

22 Syaiful Mustofa,Strategi Pembelajaran Bahasa ArabInovatif, (Malang :UIN - MALIKI Press, 2011), hlm.61.

23 Nurliya Febrisma, "Upaya Meningkatkan Kosa Kata Melalui Metode Bermain Peran Pada Anak Tunagrahita Ringan (PTK Kelas di SLB Kartini Batam), Jurnal Ilmiah Pendidikan Khusus , http://ejournal.unp.ac.id/index.php/jupekhu, hlm 112, tahun 2013, akses 15 Februari 2018, pukul 
dalam memahami materi yang baru; b) Guru membacakan mufrodat dengan baik dan benar; c) Peserta didik menirukan /melafalkan kembali tanpa membuka buku atau melihat tulisan. Langkah ini diulang berkali-kali hingga peserta didik. mampu melafalkan mufradat dengan baik dan benar sesuai dengan yang dicontohkan guru, kemudian menghafalkannya. ${ }^{24}$

Adapun tujuan pembelajaran mufrodat bahasa Arab adalah: a) Memperkenalkan kosakata baru kepada peserta didik; b) Melatih peserta didik untuk dapat mengucapakan kosakata itu dengan benar; c) Memahami makna kosakata, baik secara denotative atau leksikal (berdiri sendiri)maupun ketika digunakan; d) Mampu menggunakan kosakata tersebut dalam berekspresi, baik secara lisan (berbicara )maupun tulisan (mengarang)sesuai dengan konteks yang benar.Karena itu ukuran / indikator penguasaan kosakata peserta didik bukan terletak pada kemampuannya menggunakan kosakata tersebut dengan baik dan tepat.dengan kata lain, pembelajaran kosakata berfungsi sebagai media untuk mengembangkan kemampuan peserta didik dalam berkomunikasi dalam bahasa arab baik secara aktif maupun pasif. 25

\section{HASIL DAN PEMBAHASAN}

Pengkajian Instrumen

Langkah yang harus ditempuh, dalam menganalisis hasil penelitian adalah mengkaji instrumen penilaian tersebut. Jika instrumen yang digunakan peneliti tersebut valid dan reliabel maka hasil penelitiannya juga valid dan reliabel.

\section{Uji Validitas Instrumen}

Peneliti menggunakan bantuan software SPSS 23.0 untukmelakukan uji validitas item.Penelitian ini menggunakan satu jenis tes, yaitu tes tulis yang berbentuk multiple choice yang berjumlah 25 butir soal. Rumus yang digunakan peneliti dalam uji validitas adalah rumus pearson correlations/ product moments. Rangkuman hasil uji validitas adalah sebagai berikut :

24 Bisri Mustofa dan Abdul Hamid, Metode Dan Strategi Pembelejaran Bahasa Arab, (Malang: UINMaliki Press,2012), hlm. 63. ${ }^{25}$ Neneng L M, Pembelajaran Mufradāt (Kosakata)Dalam Pembelajaran Bahasa Arab. Jakarta.Kemenag.Go.I,Akes 6 April 2018. 
Tabel 1.1

Hasil Uji Validitas Kelas Kontrol dan Kelas Eksperimen ${ }^{26}$

\begin{tabular}{|c|c|c|c|c|}
\hline No. & Soal & $\begin{array}{l}\text { Sig. (2- } \\
\text { tailed) }\end{array}$ & $\begin{array}{c}\text { Sig. Taraf } 5 \% \\
(0,05)\end{array}$ & Keterangan \\
\hline 1. & Item 1 & 0,282 & \multirow{11}{*}{0,3} & Tidak Valid \\
\hline 2. & Item 2 & 0,236 & & Tidak Valid \\
\hline 3. & Item 3 & 0,109 & & Tidak Valid \\
\hline 4. & Item 4 & 0,355 & & Valid \\
\hline 5. & Item 5 & 0,437 & & Valid \\
\hline 6. & Item 6 & 0,484 & & Valid \\
\hline 7. & Item 7 & 0,586 & & Valid \\
\hline 8. & Item 8 & 0,428 & & Valid \\
\hline 9. & Item 9 & 0,290 & & Tidak Valid \\
\hline 10. & Item 10 & 0,500 & & Valid \\
\hline 11. & Item 11 & 0,525 & & Valid \\
\hline 12. & Item 12 & 0,515 & \multirow{19}{*}{0,3} & Valid \\
\hline 13. & Item 13 & 0,564 & & Valid \\
\hline 14. & Item 14 & 0,560 & & Valid \\
\hline 15. & Item 15 & 0,615 & & Valid \\
\hline 16. & Item 16 & 0,628 & & Valid \\
\hline 17. & Item 17 & 0,642 & & Valid \\
\hline 18. & Item 18 & 0,618 & & Valid \\
\hline 19. & Item 19 & 0,598 & & Valid \\
\hline 20. & Item 20 & 0,552 & & Valid \\
\hline 21. & Item 21 & 0,609 & & Valid \\
\hline 22. & Item 22 & 0,598 & & Valid \\
\hline 23. & Item 23 & 0,597 & & Valid \\
\hline 24. & Item 24 & 0,598 & & Valid \\
\hline 25. & Item 25 & 0,609 & & Valid \\
\hline 26. & Item 26 & 0,593 & & Valid \\
\hline 27. & Item 27 & 0,593 & & Valid \\
\hline 28. & Item 28 & 0,614 & & Valid \\
\hline 29. & Item 29 & 0,608 & & Valid \\
\hline 30. & Item 30 & 0,627 & & Valid \\
\hline
\end{tabular}

Kesimpulan dari uji validitas di atas adalah terdapat 9 item soal yang tidak valid. Keempat item soal tersebut yaitu nomor 1,2,3,9, item soal tersebut tidak digunakan oleh peneliti. Sedangkan 26 item soal lainnya dinyatakan valid dan dapat digunakan untuk perhitungan selanjutnya.

Uji Reliabilitas Instrumen

${ }^{26}$ Hasil dari penghitungan menggunanakan bantuan software spss 23.0 
Uji reliabilitas penelitian ini menggunakan rumus Cronbach's Alpha.Semua item soal dikorelasikan satu sama lain dengan teknik perhitungannya menggunakan bantuan software SPSS 23.0.

Tabel 1.2

\section{Hasil Uji Reliabilitas Kelas Kontrol dan kelas Eksperimen}

Reliability Statistics

\begin{tabular}{|r|r|}
\hline $\begin{array}{c}\text { Cronbach's } \\
\text { Alpha }\end{array}$ & N of Items \\
\hline .721 & 31 \\
\hline
\end{tabular}

Dari hasil output di atas, dapat disimpulkan bahwa nilai Cronbach's Alpha yang diperoleh adalah sebesar 0,721 yang lebih besar dari nilai Sig. reliabilitas tes subyek, yaitu sebesar 0,05.0leh karena itu, soal penelitian yang digunakan peneliti reliabel atau dapat diandalkan.

Treatment Di Kelas Eksperimen

Penerapan media gambar, dalam pembelajaran mufradât ini diterapkan langsung oleh peneliti pada jam pelajaran bahasa Arab yang telah ditentukan. Rincian kegiatan treatment di kelas eksperimen adalah sebagai berikut:

\section{Pertemuan Pertama}

Pertemuan pertama di kelas eksperimen dilaksanakan pada tanggal 31juli 2018 pukul11.20-13.10, dengan durasi waktu 80 menit yang bertempat di kelas X IPS 1.Peneliti memulai pembelajaran dengan salam kemudian mengajak peserta didik untuk mengkondisikan kelas. Setelah itu, peneliti menanyakan kabar peserta didik dilanjutkan dengan melakukan absensi.peserta didik semuanya masuk dikarenakan masih tahun ajaran baru.

Materi yang akan peneliti sampaikan yaitu tentang bacaan الَبيَتَاثُ الشَّْْصِيّةُ sesuai dengan buku paket pegangan peserta didik yang berjudul Bahasa Arab Pendekatan Saintifik Kurikulum 2013 Kelas X Semester ganjil karangan Kementrian Agama Republik Indonesia.

Peneliti memulai pembelajaran dengan memberikan mufradât tentang bacaan 'الَيآنَاتُ النَّخْصِيُّة dan meminta peserta didik untuk mengartikannya. Ketika peserta didik kesusahan dalam menjawab peneliti langsung mempraktekkan 
mufradât tersebut dan peserta didik mulai mengingatnya. Setelah itu, peneliti melafalkan satu persatu kosakata yang sudah ditulis di papan tulis dan meminta peserta didik mengikuti dengan semnangat kosakata yang telah dibacakan oleh peneliti, kemudian proses pembelajaran dengan menggunakan media gambar. Awalnya peserta didik tidak tertarik, menurut mereka kegiatan tersebut akan membosankan. Tetapi, setelah mereka mengetahui aturan dan langkah-langkah permainan tersebut, peserta didik terlihat sangat antusias dan bersemangat untuk belajar.

Langkah-langkah dari permainan tersebut adalah :1) Peneliti menyiapkan beberapa lembar kertas, dimana setiap lembar kertas berisi dengan empat kolom gambar tanpa teks bahasa arab (jumlah potongan kertas disesuaikan dengan kuantitas peserta didik);2) Peneliti membagi peserta didik dibagi menjadi 5 kelompok; 3) Peneliti memberikan beberapa lembar kertas yang berisi empat kolom gambar tersebut pada masing-masing kelompok dan meminta setiap, kelompok untuk bekerja sama mengisi dengan kosakata yang sesuai dengan gambar yang ada dikertas kemudian peneleti meminta 1 atau 2 orang membacakan hasil diskusi kelompok mereka masing-masing; 4) Peserta didik membacakan hasil diskusi di depan kelas dan diberi waktu 10 menit; 5) Siswasiswi yang belum paham kosakata diwajibkan bertanya yaitu dengan mengacungkan tangan terlebih dahulu, ada 5 siswa yang mengacungkan tangan diantaranya, Sahrul Anam, Restul Ragil, Dea Yolanda, Deeva Prasasti, Nafi Sahrul Anam yang paling cepat maka kelompok itu berhak menjawab dahulu; 6) Kelompok lain diperbolehkan menjawab mufradât yang dipertanyakan dari kelompok lain, diberi 10 poin dan kalau salah menebak diberi minus 5 poin, yang menjawab 3 orang diantaranya adalah Zahra Nabila, Muhammad Hafizh Muyassar, Khusnun Nafisah; 7) Mufradât yang dijawab peserta didik dengan benar ditempelkan di papan tulis sesuai dengan penggolongannya; 8) Peseta didik yang menang diberi reward dan yang kalah diberi punishment; 9)Setelah permainan selesai, peneliti dapat membuat kesimpulan yang dapat membangun semangat siswa untuk belajar bahasa Arab.

Pembelajaran bahasa Arab pada treatment pertama ini cukup kondusif.Peserta didik ikut aktif dalam pembelajaran, dan pembelajaran semakin menarik. Pada akhir pembelajaran, peneliti dan peserta didik mereview kembali 
mufradât yang dipelajari. Kemudian peneliti mengingatkan peserta didik untuk mempelajari materi yang berkaitan dengan tema الََيَانَاتُ النَّخْصِيّةُ mufradât yang telah dipelajari. Peneliti mengakhiri pembelajaran dengan hamdalah dan mengucapkan salam.

\section{Pertemuan Kedua}

Pada pertemuan kedua ini dilaksanakan pada tanggal 6 Agustus 2018 pukul 08.20-09.00. Seperti biasa, peneliti mengawali pembelajaran dengan salam, lalu mengajak peserta didik untuk mengkondisikan kelas karena pembelajaran akan segera dimulai. Peneliti menanyakan kabar peserta didik setelah itu melakukan absensi, dari 32 peserta didik semuanya hadir mengikuti pembelajaran. Peneliti memulai pembelajaran dengan mereview mufradât sebelumnya dengan menyampaikan mufradât dan meminta peserta didik untuk mengartikannya. Ketika peserta didik kesusahan dalam menjawab peneliti langsung mempraktekkan mufradât tersebut dan peserta didik mulai mengingatnya. Setelah itu, peneliti melanjutkan materi dengan tema yang sama (الَبانَاُ الشَخِِْيَّةُ ), hanya saja peneliti memberikan mufradât baru kepada peserta didik. Pembelajaran kali ini berlangsung santai dan nyaman, karena peserta didik sudah akrab dengan peneliti.

Peneliti menjelaskan kembali aturan dan langkah-langkah pembelajaran menggunakan media gambar, peneliti membagi 5 kelompok. Masing-masing kelompok mendapatkan kertas yang berisi gambar. Masih sama dengan pertemuan sebelumnya, perwakilan dari masing-masing kelompok maju kedepan dan mambacakan hasil mufradât yang sudah didiskusikan dengan teman sekelompoknya, dan kelompok lain menyimaknya. Bagi kelompok yang masih paham dan mengerti kosakata yang dibacakan oleh peserta didik, kelompok lain diwajibkan untuk bertanya yaitu dengan mengacungkan tangan dan kelompok yang tercepat akan mendapatkan kesempatan untuk menjawab terlebih dahulu. Pembelajaran tersebut berlangsung hingga semua kelompok selesai mempresentasikan hasil diskusi dengan kelompoknya. Semangat dan antusiasme peserta didik sangat terlihat, terbukti saat semua kertas bergambar berhasil dijawab, tetapi mereka masih ingin melakukan permainan tersebut. Hal itu membuat pembelajaran lebih menyenangkan dan tidak membosankan. 
Sebelum pembelajaran berakhir, peneliti menanyakan kembali mufradât yang baru saja dipelajari dan mufradât sebelumnya. Peneliti memberikan kesempatan peserta didik untuk bertanya jika belum jelas. Karena sudah jelas, selanjutnya peneliti mengingatkan peserta didik untuk belajar materi yang telah dipelajari untuk melaksanakan pretest pada pertemuan selanjutnya. Peneliti menutup pembelajaran dengan bacaan hamdalah dan salam.

\section{Pertemuan Ketiga dan Kegiatan Penutup}

Pertemuan ketiga dan kegiatan penutup dilaksanakan pada tanggal 7 agustus 2018. Peneliti mengawali pembelajaran dengan salam, menanyakan kabar dan melakukan absensi peserta didik. Seluruh peserta didik hadir, dengan jumlah 32 peserta didik. Pertemuan kali ini peneliti masih membahas materi sebelumnya. Peneliti dan peserta didik mengulang semua mufradât yang telah diajarkan selama 20 menit. Setelah itu, peneliti menjelaskan bahwa pada pertemuan ini peserta didik melaksanakan posttest. Posttest dilaksanakan selama 40 menit (1 jam pelajaran).

Posttest dilaksanakan untuk mengukur penguasaan mufradât peserta didik setelah diterapkannya treatment berupa penerapan media gambar. Soal posttest berjumlah 25 dengan jenis soal multiple choice. Siswa mengerjakan soal posttest secara individu danpelaksanaan posttest berjalan dengan lancar. Peneliti menutup pertemuan dengan mengucapkan terima kasih kepada seluruh peserta didik X IPS MTs MAN 3 Bantul Yogyakarta yang telah berpartisipasi secara aktif dalam pelaksanaan penelitian ini.

Analisis Data

Penelitian ini menggunakan teknik analisis kuantitatif untuk mengolah data pretest, posttest, dan Uji " $\mathrm{t}$ ". Sebelum peneliti menganalisis data, berikut merupakan hasil nilai pretest dan posttest antara kelas eksperimen dan kelas kontrol. Adapun data hasil pretest dan posttest kelas kontrol adalah hasil pretest dan posttest di kelas non-eksperimen mengalami peningkatan dari 63,031 menjadi 66,312. Dan dari hasil tersebut diperoleh peningkatan sebesar 8,625. Sedangkan 
hasil pretest dan posttest di kelas eksperimen mengalami peningkatan dari 66,625 menjadi 90,125. Dan dari hasil tersebut diperoleh peningkatan sebesar 21,375.

\section{Uji Normalitas}

Uji normalitas dilakukan terhadap nilai hasil pretest dan posttest kelas eksperimen dan kelas kontrol.Uji normalitas dalam penelitian ini dilakukan dengan menggunakan Uji Kolmogorof-Smirnov (K-S) dengan bantuan software SPSS 23.0 .

Dasar pengambilan keputusan dalam uji normalitas adalah :a) Jika nilai signifikansi $>0,05$, maka data berdistribusi normal; b) Jika nilai signifikansi $<0,05$, maka data tidak berdistribusi normal.

Data hasil dari uji normalitas dengan menggunakan Uji Kolmogorof-Smirnov (K-S) yaitu sebagai berikut :

Tabel 1.3

\section{Data Hasil Uji Normalitas Kelas Kontrol}

\begin{tabular}{|c|c|c|c|c|}
\hline No. & Kelas & $\begin{array}{c}\text { Sig. Kolmogorov- } \\
\text { Smirnov }\end{array}$ & $\begin{array}{c}\text { Sig. (2- } \\
\text { talied) }\end{array}$ & Keterangan \\
\hline 1. & Pretest Kontrol & 0.188 & 0.006 & $\begin{array}{c}\text { Distribusi } \\
\text { Normal }\end{array}$ \\
\hline 2. & Posttest Kontrol & 0.148 & 0.074 & $\begin{array}{c}\text { Distribusi } \\
\text { Normal }\end{array}$ \\
\hline
\end{tabular}

kemampuan hasil pretest kelas kontrol diperoleh Sig. =0,006 yang artinya 0,188> 0,05 sehingga data tersebut berdistribusi normal. Dan kemampuan hasil posttest diperoleh signifikansi sebesar Sig. $=0,148$ yang artinya $0,148>0,05$. Sehingga data tersebut juga berdistribusi normal.Kesimpulan dari hasil pretest dan posttest peserta didik kelas eksperimen yaitu data berdistribusi normal.

Pengujian normalitas juga dilakukan terhadap hasil pretest dan posttest kelas eksperimen. Hasil dari uji normalitas data peserta didik adalah sebagai berikut:

Tabel 1.4

\section{Data Hasil Uji Normalitas Kelas Eksperimen}

\begin{tabular}{|c|c|c|c|c|}
\hline No. & Kelas & $\begin{array}{c}\text { Sig. Kolmogorov- } \\
\text { Smirnov }\end{array}$ & $\begin{array}{l}\text { Sig. (2- } \\
\text { tailed) }\end{array}$ & Keterangan \\
\hline
\end{tabular}




\begin{tabular}{|c|c|c|c|c|}
\hline 1. & $\begin{array}{c}\text { Pretest } \\
\text { Eksperimen }\end{array}$ & 0,179 & 0,011 & Distribusi Normal \\
\hline 2. & $\begin{array}{c}\text { Posttest } \\
\text { Eksperimen }\end{array}$ & 0,167 & 0,023 & Distribusi Normal \\
\hline
\end{tabular}

Dari data output tests of normality di atas, maka diperoleh nilai Sig. pretest untuk kelas eksperimen sebesar 0,179 dan kelas kontrol 0,188. Karena nilai pretest dan posttest di atas memiliki nilai Sig. yang lebih dari 0,05, dapat disimpulkan bahwa data nilai pretest dan posttest peserta didik kelas eksperimen berdistribusi normal. Jadi salah satu syarat Uji "t" telah terpenuhi.

Uji Homogenitas

Uji homogenitas dilakukan terhadap nilai hasil pretest dan posttest kelas kontrol dan kelas eksperimen.Uji homogenitas dalam penelitian ini dilakukan dengan menggunakan bantuan software SPSS 23.0. Pengambilan keputusan untuk uji homogenitas data ini adalah sebagai berikut :

$$
\begin{aligned}
& \mathrm{H}_{\mathrm{a}}=\text { Data bersifat Homogen } \\
& \mathrm{H}_{0}=\text { Data tidak bersifat Homogen }
\end{aligned}
$$

Dasar pengambilan keputusan dalam uji homogenitas adalah sebagai berikut :

Jika nilai signifikansi $>0,05$, maka data $\mathrm{H}_{\mathrm{a}}$ diterima.

Jika nilai signifikansi $<0,05$, maka data $\mathrm{H}_{0}$ ditolak.

Hasil uji homogenitas nilai pretest antara kelas eksperimen dan kelas kontrol adalah :

Tabel 1.5

\section{Data Hasil Uji Homogenitas Nilai Prestest antara Kelas Eksperimen dan Kelas Kontrol Test of Homogeneity of Variances}

Hasil Belajar Siswa

\begin{tabular}{|c|c|c|c|c|}
\hline Levene Statistic & $\mathrm{df1}$ & $\mathrm{df} 2$ & Sig. & Keterangan \\
\hline .561 & 1 & 62 & .457 & Homogen \\
\hline
\end{tabular}

Berdasarkan uji Test of Homogeneity of Variances terhadap nilai pretest kelas eksperimen dan kelas kontrol di atas dapat dilihat bahwa nilai pretest antara kelas eksperimen dan kelas kontrol diperoleh Sig. $=0,457$. Dan dari hasil tersebut dapat disimpulkan bahwa $\mathbf{H}_{\mathbf{a}}$ diterima karena 0,457 $>$ 0,05. Dengan demikian dapat 
disimpulkan bahwa data tersebut bersifat homogen. Hasil uji homogenitas nilai posttest antara kelas eksperimen dan kelas kontrol yaitu :

Tabel 1.6

\section{Data Hasil Uji Homogenitas Nilai Posttest antara}

Kelas Eksperimen dan Kelas Kontrol

Test of Homogeneity of Variances

hasil belajar siswa

\begin{tabular}{|c|r|r|c|}
\hline $\begin{array}{l}\text { Levene } \\
\text { Statistic }\end{array}$ & df1 & df2 & Sig. \\
\hline 1.392 & 1 & 62 & .243 \\
\hline
\end{tabular}

Pada uji Test of Homogeneity of Variances di atas dapat dilihat bahwa nilai posttest bahasa Arabkelas eksperimen dan kelas kontrol memiliki Sig. =0,243. Dan dari hasil tersebut dapat disimpulkan bahwa $\mathbf{H}_{\mathbf{a}}$ diterima karena 0,243>0,05. Jadi dapat disimpulkan bahwa data tersebut bersifat homogen. Dari dua uji prasyarat di atas, uji homogenitas dan uji normalitas, diketahui bahwa data nilai seluruh peserta didik berdistribusi normal dan homogen. Oleh karena itu, terpenuhilah prasyarat penggunaan Uji " $t$ " untuk analisis data selanjutnya.

Pengujian Hipotesis

Setelah diperoleh bahwa data berdistribusi normal dan homogen, maka langkah selanjutnya adalah melakukan Uji " $\mathrm{t}$ " Independent-Samples Test untuk melakukan uji hipotesis.

Adapun dasar pengambilan keputusan dalam hitungan ini dalah sebagai berikut : a) Jika nilai signifikasi atau Sig. (2-tailed) > 0,05, maka $\mathrm{H}_{\mathrm{a}}$ ditolak dan $\mathrm{H}_{0}$ diterima; b) Jika nilai signifikasi atau Sig. (2-tailed) < 0,05, maka $\mathrm{H}_{\mathrm{a}}$ diterima dan $\mathrm{H}_{0}$ ditolak.

Pengujian hipotesis dalam penelitian ini menggunakan program software SPSS 23.0.Hasil Uji " $\mathrm{t}$ ” nilai pretest kelas eksperimen dan kelas kontrol, sebagai berikut :

\section{Tabel 1.7}

\section{Hasil Uji “t” Independent Samples Test Pretest}

Kelas Eksperimen dan Kelas Kontrol

\begin{tabular}{|c|c|c|c|c|}
\hline No. & Data & Mean & Sig (2-tailed) & Keterangan \\
\hline 1. & Pre-Eksperimen & 51.69 & 0,985 & Tidak Signifikan \\
\hline
\end{tabular}




\begin{tabular}{|c|c|c|c|c|}
\hline 2. & Pre-Kontrol & 51.75 & 0,985 & Tidak Signifikan \\
\hline
\end{tabular}

Pada tabel di atas menunjukkan bahwa Sig. (2-tailed) untuk pretest kelas eksperimen dan kelas kontrol adalah sebesar 0,985. Angka tersebut ternyata $>$ dari 0,05. Maka sesuai dengan pengambilan keputusan dalam Uji " $\mathrm{t}$ " Independent Sample Test disimpulkan bahwa $\mathrm{H}_{0}$ diterima yang artinya tidak terdapat perbedaan hasil belajar mufradât yang signifikan antara kelas eksperimen dan kelas kontrol. Hal ini membuktikan bahwa penguasaan awal mufradât antara kelas eksperimen dan kelas kontrol tidak jauh berbeda atau sama.

Setelah diketahui bahwa tidak ada perbedaan yang signifikan antara kelas eksperimen dan kelas kontrol, langkah selanjutnya yaitu membandingkan nilai posttest antara kelas eksperimen dan kelas kontrol. Adapun Uji " $\mathrm{t}$ ” pada nilai posttest kedua kelas tersebut adalah sebagai berikut :

Tabel 1.8

\section{Hasil Uji “t” Independent Samples Test Posttest}

\section{Kelas Eksperimen dan Kelas Kontrol}

\begin{tabular}{|c|c|c|c|c|}
\hline No. & Data & Mean & Sig. (2-tailed) & Keterangan \\
\hline 1. & Post-Eksperimen & 84.63 & 0,000 & Signifikan \\
\hline 2. & Post-Kontrol & 68.59 & 0,000 & Signifikan \\
\hline
\end{tabular}

Dari diskripsi tabel di atas, dapat dilihat bahwa Sig. (2-tiled) untuk posttest kelas eksperimen dan kelas kontrol adalah sebesar 0,000. Angka tersebut menunjukkan bahwa ternyata 0,000< dari 0,05. Maka sesuai dengan pengambilan keputusan dalam Uji “t” Independent Sample Test disimpulkan bahwa $\mathbf{H}_{\mathbf{a}}$ diterima yang artinya terdapat perbedaan yang signifikan nilai posttest antara kelas eksperimen (yang menggunakan media gambar) dengan kelas kontrol (yang tidak diterapkan media apapun).

Dari penjelasan di atas, dapat diambil kesimpulan bahwa pembelajaran mufradât menggunakan media gambar pada kelas eksperimen dinilai berpengaruh dalam hasil belajar peserta didik baik dari segi hasil maupun proses dibandingkan dengan pembelajaran mufradât pada kelas kontrol yang dalam pembelajarannya tanpa menggunakan media apapun.

\section{KESIMPULAN}

Berdasarkan hasil penelitian dan pembahasan penelitian dapat ditarik kesimpulan yaitu terdapat perbedaan yang signifikan dalam pembelajaran 
mufradât antara kelas eksperimen (menggunakan media gambar)dengan kelas kontrol (tanpa menggunakan media gambar).

Dapat dilihat dari nilai rata-rata posttest kelas eksperimen sebesar 90,125 sedangkan kelas kontrol sebesar 66,312. Selisih dari nilai rata-rata skor di atas yaitu 23,813. Hal ini juga dibuktikan dari hasil analisis Uji "t" yang menunjukkan bahwa nilai Sig. 0,000 $<0,05$ dan sesuai dengan pengambilan keputusan Independent Sample Test yang hasilnya bahwa $\mathbf{H}_{\mathbf{a}}$ diterima. Dari analisis di atas dapat ditarik kesimpulan bahwa penerapan media permainan gambar lebih efektif digunakan dalam pembelajaran mufradât di kelas X IPS MAN 3 BantuLYogyakarta T.A 2018/2019.

\section{DAFTAR PUSTAKA}

AECT "Association For Education and Communication". 1998 dalam Arabiya. Kairo: Dar Al-Ma'rif.

Ahmad, Salim Muhammad. 1987,Al-Wasa'il Al-Ta'limiyah Fi Ta'limi Al-'Arabiyah Lughah Ajnabiyah. Mekkah: Al-Mamlakah Al-'Arabiyah Al-Su'udiyah.

Arsyad, Azhar. 2010. Bahasa Arab dan Metode Pengajarannya. Yogyakarta.

Hamalik, Oemar. 2003. Kurikulum Dan Pemebelajaran. Jakarta: Bumi Aksara.

Hamalik, Oemar. 1980. Media pendidikan. Jakarta: PT.Citra Aditya Bakti.

Hamid, Bisri Mustofa Dan Abdul. 2012. Metode Dan Strategi Pembelejaran Bahasa Arab. Malang:UIN-Maliki Press.

Hamid, M Abdul. 2008. Pembelajaran Bahasa Arab:Pendekatan, Metode, Strategi, Materi dan Media. Malang: UIN Maliki Press

Ibrahim, Abdul Halim. 1968. Al-Muwajjih Al-Fanni Li Mudarrisi Al-Lughah Al-Koyok. Media pendidikan. Jakarta: Depdikbud.

Khalilullah, M. 2012. Media Pembelajaran Bahasa Arab. Yogyakarta: Aswaja Pressindo.

M, Neneng L . Pembelajaran Mufradāt (Kosakata)Dalam Pembelajaran Bahasa Arab. Jakarta.Kemenag.Go.I

Misbahudin dan Iqbal Hasan. 2013. Analisis Data penelitian Dengan Statistik, Jakarta: PT Bumi Aksara. 
Muin, Abdul. 2004. Analisis Kontrastif Bahasa Arab Dan Bahasa Indonesia Telaah Terhadap Fonetik Dan Morfologi. Jakarta: Pustaka Al Husna Baru.

Mustofa, Syaiful. 2011. Strategi Pembelajaran Bahasa Arab Inovatif. Malang: UIN MALIKI Press.

Nababan, Sri Utami. 1993. Metodologi Pengajaran Bahasa. Jakarta: Gramedia.

Nasirun, Saidi. 2014. Upaya Meningkatkan Memahaman Mufradāt Melalui Metode card Sort pada Pembelajaaran Bahasa Arab kelas IV Semester II di MI Nurul Hidayah Trenten Candimulyo magelang tahun 2014'. Skripsi Pendidikan guru Madrasah Ibidaiyah. Yogyakara:UIN Sunan Kalijaga.

Riyanto, Theo. 2002. Pembelajaran Sebagai Proses Bimbingan Pribadi. Jakarta: PT.Grasindo.

Suleiman, Amir Hamzah 1998. Media Audio Visual Untuk Pengajaraan, telaah Terhadap Fonetik Dan Morfologi. Jakarta: Pustaka Al Husna Baru.

Sutjipto, Cecep Kustandi dan Bambang. 2011. Media Pembelajaran Manual dan Digital. Bogor: Ghalia Indonesia.

Wardana, Mahrus Ali. 2016. Peningkatan Kualitas Hafalan Kosakata Bahasa Arab Dengan media Permainan Teka-teki silang (Studi Eksperimen Pada Siswa Kelas X Di MA Ali Maksumtahun ajaran 2016/2017). Skripsi Pendidikan bahasa Arab. Yogyakarta: UIN Suanan Kalijaga 